\title{
Regulation in Practice: Power, Resources and Context at the Local Scale in UK Food Retailing
}

\begin{abstract}
This article uses a relational lens to explore the conflict between the regulatory state and a leading food retailer seeking store expansion within one catchment in south-east England over an eight year period. The research highlights the relational power geometries which play out in context between regulators and a regulated corporate firm to emphasise the role of power, resources, and scale. The research teases out how the power of the state to uphold an interpretation of market rules is compromised by a lack of responsiveness compared to both the proactive and reactive tactics of the well-resourced corporate retailer. It recognises how multiple regulatory agents of the state with divergent goals, sometimes situated across different spatial scales of governance, can produce markedly different judgements resulting in outcomes that are not in the public interest. Such situations require swift and coherent regulatory responses and can reveal the need for changes to the organisation of the regulatory infrastructure itself.
\end{abstract}

Keywords: relational geography, power, regulation, food retailing

\section{Steve $\mathbf{W o o d}^{\circ}$ and Andrew Alexander.}

The Surrey Business School, University of Surrey, Guildford, Surrey GU2 7XH, UK.

${ }^{\circ}$ Corresponding author: Email: $\underline{\text { sm.wood@ surrey.ac.uk }}$

Authors' version - accepted at Environment and Planning A (April 2016).

If citing please refer to the published version

\section{Acknowledgements}

We would like to thank Leigh Sparks for his helpful comments on previous drafts of this paper as well as the editor and three anonymous referees for their generous and helpful comments which aided us in sharpening our argument. The manuscript benefits from discussions with Christine Reeves (Reeves Retail Planning Consultancy); Shane Brennan (Association of Convenience Stores); Simon Bills (McKinsey \& Co); Steve Jones (IGD); Clive Black (Shore Capital) and Richard Quinn (formally of the Co-operative Group). We appreciate comments received when we presented the paper at 4th Global Conference on Economic Geography, University of Oxford, August 2015. The first author was employed by Tesco plc in its Marketing Department between 2002-2005 - however, the research described in this paper is not reliant in any way on insights gained as a result of this employment. As always, all errors or omissions remain the responsibility of the authors. 


\title{
Regulation in Practice: Power, Resources and Context at the Local Scale in UK Food Retailing
}

\begin{abstract}
This article uses a relational lens to explore the conflict between the regulatory state and a leading food retailer seeking store expansion within one catchment in south-east England over an eight year period. The research highlights the relational power geometries which play out in context between regulators and a regulated corporate firm to emphasise the role of power, resources, and scale. The research teases out how the power of the state to uphold an interpretation of market rules is compromised by a lack of responsiveness compared to both the proactive and reactive tactics of the well-resourced corporate retailer. It recognises how multiple regulatory agents of the state with divergent goals, sometimes situated across different spatial scales of governance, can produce markedly different judgements resulting in outcomes that are not in the public interest. Such situations require swift and coherent regulatory responses and can reveal the need for changes to the organisation of the regulatory infrastructure itself.
\end{abstract}

Keywords: relational geography, power, regulation, food retailing

\section{Introduction}

The nature of market rules and the state's practical enforcement of regulation on economic activity, along with its effects on the urban environment, have been long-standing concerns for economic geographers. While there is an appreciation that that the regulatory power of nations is partly compromised given multi-scalar geographies of governance (Jessop, 2004), there remains a central role for the 'regulatory state' in its 'application of informal and formal bureaucratic rule making, rule monitoring, and rule enforcement' (Levi-Faur, 2013, p 30; Gouldson and Sullivan, 2014; Wood, 2013). The contextual intersection of regulation, regulatory agencies, and corporate strategy lie at the heart of this article - something we explore and illustrate through an in-depth case study of UK retail development within a large urban catchment over an eight year period.

While there have been numerous explorations of regulation in the retail industry within this journal (e.g. Wood, 2001; Wrigley, 2001; Wrigley et al., 2009), they have often charted the 
emergence of particular regulations (e.g. land-use planning) and the implications for particular retail formats. Distinctively, this paper seeks to make a wider theoretical contribution relating to the challenges of regulating economic space by tracing the power geometries which play out between regulators and the regulated corporate firm. A relational perspective particularly exposes the role of power, resources, and scale in particular contexts. The research explores how the power of the state to uphold an interpretation of market rules is compromised by a relative lack of resources and subsequent responsiveness compared to the well-resourced corporate retail firm. We find that multiple regulatory agents of the state with divergent goals, sometimes situated across different spatial scales of governance, can produce markedly different judgements resulting in outcomes that are not in the public interest. Such situations require swift and coherent regulatory responses to prevent the emergence of uncompetitive geographies and can reveal the need for changes to the organisation of the regulatory infrastructure itself.

The paper is structured as follows: first, we briefly explore the relational nature of regulatory implementation within the economic geography literature; in doing so, emphasising the importance of sensitivity to context and the role of resources, power and scale. Second, we provide important contextualisation with regards to land-use planning and competition regulation in UK retailing, which leads to third; an in-depth case study which provides an empirical exploration of the conflict between the regulatory state and a retailer within one catchment in south-east England over an eight year period. Our final section reflects on the theoretical contribution of the article as well as the retail sector specific implications of the research.

\section{The Relational Nature of Regulatory Implementation: Resources, Power and Scale}

Our focus in this article is on the intersection of corporate strategy, regulation and the state's regulatory enforcement, in our case related to matters of retail land use planning and competition regulation. Bathelt and Glückler (2014) suggest institutions are the relatively stable interactions between economic agents that develop upon rules and regulations in contingent ways. Importantly, rules themselves are not always fully institutionalised. As such, institutions may represent the intentions inherent within rules, yet they may 'unfold in practices that deviate to a greater or lesser extent, or even disregard them. Therefore, rules are fundamentally different from institutions - they are "not yet institutions" (ibid., p 356). A relational perspective is therefore helpful for us in exploring regulation in practice; to infuse 
an understanding of the role of agents (and their interaction) in actively shaping the environment ( $c f$. Jones, 2014). While rules, laws and regulations are codified prescriptions that can be 'written up and shared', they are rendered meaningless 'if common practices disregard or deviate from them without identifiable sanctions' (Bathelt and Glückler, 2014, p 346).

By being sensitive to the socio-spatial relations between economic actors and wider institutions at various spatial scales, we can uncover the heterogeneous configurations of power relations or 'relational geometries' that are constituted through the ebb and flow between agents. As Yeung (2005) acknowledges, relational geometries are neither actors nor structures as such, but are instead configurations of relations which connect actors and structures through horizontal and vertical power relations. Importantly, they are not static but dynamic and evolve through contextual interaction. Yeung argues such a conceptual framing that emphasises positions in relational geometries and practice through interaction allows us to avoid two polarised perspectives within economic geography: actor networks on the one hand and institutional structures on the other. Our sensitivity to situational context, interpretation and issues of power in affecting relational geometries between actors is particularly illuminating for understanding the process of regulation - it takes the agency of actors seriously and can aid us in examining what constitutes and constrains it (Faulconbridge, in press). As Clark (1992, p 619-620) argued, regulatory frameworks 'require interpretation as they are applied to specific situations' and therefore, 'only in specific contexts is the meaning of identified rules determinately defined'. This places an onus on 'competing arguments about the significance of changing circumstances for the integrity of rules' and ultimately 'how those circumstances are accommodated within the inherited institutional context' (ibid, p 620). Clark therefore argues that 'real' regulation should be framed as a set of social practices in overlapping contests for power with the state tasked with an interpretative role in making decisions about the significance of these competing representations.

Firms are thus challenged to embed themselves within their institutional and competitive contexts while mobilising their resources to their best advantage. In doing so, they attempt to influence state policies at various regulatory scales, 'seeking to construct them in ways that favour and help secure their interests' (Hsu, 2012, p 392). Firms are active in their negotiation with state agencies and pursue intense bargaining relationships with stakeholders 
across a range of industries, whether they are domestically or internationally focused (see Coe and Yeung, 2015). As such, corporations are unlikely to be the passive targets of interventions from the regulatory state and will 'deploy a range of tactics to shape the governance conditions under which they operate' (Gouldson and Sullivan, 2014, p 2975). Within retailing for example, this agency at various spatial scales is evident in responding to (and affecting) regulation at a national level in host markets as part of international expansion (Sparks, 2008), or equally appealing against local decisions within specific local geographies in domestic markets (Guy and Bennison, 2007). This places an emphasis on the availability and usage of resources by corporate actors as well as by state level agents, whether this is in the form of material resources, knowledge, power or social capital (Bathelt and Glückler, 2005).

Actively employing resources naturally leads to power asymmetries between actors. Of course, we do not necessarily reduce power down simply to coercion from the powerful to the powerless. We are conscious that different forms of power can be leveraged at different times (e.g. authority; coercion; domination, manipulation, seduction) (Allen, 2003; Faulconbridge, 2012). Importantly, Allen (2008) frames power as a 'relational social interaction', rather than power being the ability to act per se. Furthermore, he argues that resources alone do not result in power - instead it is in context and through the leveraging of those resources that power becomes evident. There is also a temporal aspect to this process, as over time 'the interplay of opposing forces shifts [...] what works best to obtain leverage may also shift, as well may the effectiveness of any particular action' (Allen, 2008, p 1618). As Faulconbridge (2012) argues, there is a recognised need not only to conceptualise the role of power relations in a conceptual sense, but also explore at the 'micro-scale' to understand 'how actors become powerful in time-place specific ways' ( $p$ 736). This is not to necessarily privilege local-scale interactions and does not dismiss the role of structural power of the state ( $c f$. Sunley, 2008), but does seek to recognise the dynamism of the practice of regulation and thus resist an excessively structuralist view. Drawing on Allen's (2003) 'modalities of power', Faulconbridge (2012) contends that such fine grained analysis involves scrutinizing the different forms of power constructed by actors, as well as the 'whereabouts' of power which includes the way geography shapes assets that construct power, the nature of interactions between relevant parties and the power relations produced. It is at this contextspecific local level we can start to uncover the relational and multi-scalar interaction of 
agents of the regulatory state, and their processes of interpretation and enforcement in response to highly adaptive firm-level tactics.

This section has served to provide a conceptual lens through which to assess our case study relating to corporate (retail) activity intersecting with the role of the regulatory state. In doing so, we have emphasised the need to adopt a relational perspective through which to analyse interactions between corporate tactics and the interpretation and enforcement of government regulation. Such a contextual outlook requires a sensitivity to issues of scale, power and resources. In the following section, we provide important background to regulation and the regulators within UK retailing which provides context to the case study.

\section{Land-Use Planning and Competition Regulation in UK Food Retailing}

The leading food retailers in the UK are renowned for their transformative effects on the structure of towns and cities (Clarke et al., 2012) with the entry of large format retailers frequently contested by the public and local authorities alike. Notwithstanding the mixed evidence on the effects of retail development (Powe, 2012; Wrigley and Dolega, 2011), there is a key role for government in regulating the geography of retail expansion. Broadly speaking, in the UK, this is operationalised through two forms of regulation: first, retail landuse planning policy which is set by central government and implemented at a local authority level. Second, retail competition policy which is administered by national regulators and assessed at a national, regional or a local scale dependent on the size and effects of the issue concerned.

\section{The role of $U K$ retail land-use planning regulation}

Since the mid-1990s, UK retail land-use planning policy has exhibited a focus on directing retail expansion towards town centres rather than out-of-centre. The progressive 'tightening' of retail land-use planning policy since a more permissive approach to out-of-town retail development during the 1980s throughout the UK is expertly explained elsewhere (Guy, 2007). However, it is important to note the landmark revision to England's Planning Policy Guidance Note 6 (PPG6) in 1996 that signalled the start of robust "town centre first" governance of development planning chiefly through the so-called sequential test that prioritised retail investment in established centres, with similar tightening occurring elsewhere across the UK (Wrigley, 1998). In addition, local authorities were required to undertake an assessment of the impact of proposals for retail developments larger than 2,500 
square metres gross floorspace. The essence of "town centre first" has largely continued through the evolution of retail land-use planning policy across the UK since 1996 Within this plan-led approach, local planning authorities are responsible for drawing up Local Plans that allocate a range of suitable sites to meet the nature and scale of development needed.

The highly directive approach of UK retail planning policy remains contested, with numerous multiple food retailers referring to its restrictive nature (Guy and Bennison, 2007) with particular concerns that it compromises retail productivity (Cheshire et al., 2015). Furthermore, its efficacy is questioned with data suggesting that town centres continue to lose share of sales and retail space to out-of-town locations (Wrigley and Lambiri, 2014). More widely, the leading food retailers have been recognised as highly adaptive to the demands of planning policy, often engaging both in short-term tactical and more enduring strategic initiatives to enhance market position and to lock-in strategic locations (Wood et al., 2010).

It is notable that retail land-use planning policy does not consider the fascia or retail brand of the applicant; instead focusing 'on the character and use of land, rather than the identity of a proposed occupier' (Hughes et al. 2009, p 572). This has allowed a steady creep of the leading food retailers organically growing on a store-by-store basis to achieve dominance within numerous local catchments (Wrigley, 2010). Such a regulatory status-quo was challenged when the most recent Competition Inquiry into the Groceries Market advocated the incorporation of a so-called Competition Test within land-use planning policy. The proposed test would have seen central government (Office of Fair Trading - hereafter 'OFT') advising local planning authorities on decisions relating to stores (over 1,000 sq m) within individual catchments. Retailers would pass the test and thereby receive permission to develop their store if there was adequate food retail competition already present within the catchment (Competition Commission [CC], 2008). However, the implementation of the Test was prevented by a successful appeal to the Competition Appeal Tribunal (CAT) by the UK's largest retailer, Tesco that was related to the failure to take into account the economic costs of such a proposed test (CAT, 2009). It has not subsequently been revised as government's appetite for additional regulation appeared to evaporate in the economic downturn, with concerns instead focusing on economic sustainability. 


\section{The role of UK retail competition policy - market power at local and national scales}

UK competition policy with regards to retailing aims to deter non-competitive conduct within retail market structures (Dobson, 2006). It is widely known that concentration levels have increased markedly within food retailing across Europe, the US and particularly within the UK (Poole et al., 2006). Concerns over the degree of market power afforded to relatively few leading retailers in the UK groceries market led to five inquiries by regulators between 1981 and 2008. While no wide ranging or systematic anti-competitive issues were identified, concerns persist regarding potential abuses of market power.

The regulatory agents involved in policing and adjudicating on competition matters during the period under review in this paper were the Office of Fair Trading (OFT) and the Competition Commission. For mergers and other market investigations a two-step process was pursued with the OFT making an initial assessment and then referring cases of concern to the Competition Commission for a full investigation. The dual agent approach to the assessment and enforcement of competition policy between the OFT and Competition Commission changed in 2014 when the Competition and Markets Authority (CMA) took over many of the functions of both agencies.

National concentration levels and their implications for market power are important to consider. This is a particular concern in the case of food retailing as leading retailers occupy a gatekeeper role with suppliers and may 'control and shape the terms and conditions of trade in their favor' (Dobson, 2006, p 531). The relational power of such retailers over suppliers is evident in their role as customers to suppliers in purchasing stock, but also as competitors with the development and promotion of their own/private label ranges. Furthermore, retailers control the allocation of shelf-space within stores so literally govern the nature of supplier access to the customer. Such pressures create a situation where leading food retailers can leverage their position to obtain low prices and secure other benefits from suppliers (Dobson and Chakraborty, 2008).

While a focus on national concentration levels is important, there is also substantial variability of market shares and concentration at the local, catchment level (Poole et al., 2006). Of course, food retail markets are typically local in the manner in which consumers experience them (Clarke et al., 2012) and therefore regulators analyse at this scale when considering the implications of a particular retail acquisition or of high concentration ratios 
more generally. The local dominance of one retailer can mean that it may offer suppliers the only realistic opportunity to access customers within the catchment. There are also concerns for consumers when there are low levels of local inter-fascia competition given the potential for price discrimination (Dobson and Waterson, 2005).

The approach for the analysis of mergers within UK retailing has become formalized through a number of cases in the 2000 s to correct transactions that were considered to be uncompetitive. There is a particular appetite to intervene in circumstances:

'...where a merger involves competing firms supplying competing products (so-called 'horizontal mergers') and may remove the rivalry between them, allowing the merged firm profitably to raise prices (so-called 'unilateral effects')' (CC/OFT, 2011, p.5)

Spatial scale is important here, with scope for local as well as national intervention. At the local scale, catchment area analysis is undertaken utilizing drivetimes ('isochrones') to represent customer accessibility and therefore identify which stores' catchments overlap to eliminate unproblematic areas from further analysis by regulators. A particular focus is on the use of econometric techniques to determine the implications for pricing and consumer choice within specific catchments as well as nationally (CC/OFT, 2011). Where limited areas of excessive horizontal market overlap occur, selective divestment of store(s) may be required. If there are more systematic competition concerns at the national or regional level, the acquirer may be blocked outright.

We now attempt to situate many of the theoretical debates discussed at the start of the paper concerning the interpretative nature of regulation, resources, power and scale within an empirical case study. The case approach allows us to explore the relational geometries that play out between the numerous institutional actors which interpret and impose market rules at different scales (see Table 1), and the corporate retail firm keen to re-make their store geographies to their best advantage. 
Table 1: Regulatory Enforcement in the Geography of UK Retail Expansion: Institutional Actors and Spatial Scale

\begin{tabular}{|c|c|c|}
\hline & $\begin{array}{l}\text { Competition regulation in merger } \& \\
\text { acquisitions }\end{array}$ & Land-use planning regulation \\
\hline Objectives & $\begin{array}{l}\text { Seeks to address situations that may } \\
\text { otherwise lead to a "Substantial } \\
\text { Lessening of Competition" }\end{array}$ & $\begin{array}{l}\text { Controls the organic (new site) individual } \\
\text { permissions for the opening of stores and } \\
\text { change of use matters } \\
\text { Focus on directing retail development to } \\
\text { established town and city centres }\end{array}$ \\
\hline Institutional actors & $\begin{array}{l}\text { Office of Fair Trading and } \\
\text { Competition Commission } \\
\text { (since } 2014 \text { this has been combined } \\
\text { into the Competition and Markets } \\
\text { Authority [CMA]) }\end{array}$ & $\begin{array}{l}\text { Local Authorities (using guidance from } \\
\text { National Government - e.g. National } \\
\text { Planning Policy Framework, 2012) }\end{array}$ \\
\hline $\begin{array}{l}\text { Spatial scale of } \\
\text { regulatory } \\
\text { assessment }\end{array}$ & $\begin{array}{l}\text { Regulator-national } \\
\text { Assessment - national, regional, local } \\
\text { scale (dependent on the size and effects } \\
\text { of the transaction) }\end{array}$ & $\begin{array}{l}\text { Regulator - local authority } \\
\text { Assessment - local catchment level }\end{array}$ \\
\hline
\end{tabular}

Our case study explores the store development of the UK's largest food retailer, Tesco plc in one large catchment within close proximity to London over an eight year period. In many respects, this may be considered an 'extreme' case given the unprecedented level of resources dedicated by regulators to addressing concerns relating to the acquisition of a single store and the length of time taken to resolve the issues at hand. Such 'extreme' or 'outlier' cases 'often reveal more information because they activate more actors and more basic mechanisms in the situation studied' (Flyvbjerg, 2006, p 229). While the degree of generalizability is limited with extreme events, they can also illustrate processes that are operating in other cases though at a more acute level. In this case, we track the exchange between the corporate and regulatory actors through the analysis of a range of regulatory reports and working papers both from central government and located within the archives of a local council as well as relevant national and local media reports. We have also triangulated our understanding of events through discussion with industry executives and retail analysts who are familiar with the case and its implications more widely.

\section{Case Study: Tesco versus the regulatory state at the local scale}

\section{Background to case study}

Slough is a town in the county of Berkshire in England, some 22 miles west of London, with a population of approximately 120,000 (CC, 2007c). In 2003, the town was seemingly well served by food superstores. Figure 1 shows the local area of interest, notably containing a 
46,000 sq ft superstore owned by the Co-operative Group Ltd (Uxbridge Road - hereafter 'CGL' store) situated $350 \mathrm{~m}$ east of the town centre. Directly to the west of the CGL store, at a distance of $800 \mathrm{~m}$ lay a 60,000 sq ft hypermarket (Tesco Brunel Way). Stores at a further distance from the CGL store included a 15,000 sq ft Safeway at a 5-10 minute drivetime to the north-west; a 59,000 sq ft Asda at a 10 minute drivetime to the west and a 32,000 sq ft Sainsbury's at a 10-15 minute drive to the north-west. While there were also smaller stores within the immediate catchment, these are excluded from Figure $\mathbf{1}$ as they were considered by the competition authorities to be in a separate and distinct food retail market. What follows is a detailed assessment of the eight year exchange between a corporate retail firm and regulators - it charts the relational geometries between the key actors to provide insights into the interpretive nature of regulation that are embedded within issues of power, resources, context and scale.

Take in Figure 1

\section{Strategic acquisition and on-site replacement}

In March 2003, the Co-operative Group began marketing its Slough store to interested parties. The store was to be sold because it was underperforming and the retailer was retreating from operating superstores due to its inability to compete with the leading large format grocery retailers. Instead, it intended to further develop smaller, convenience sized stores with the 'recycling of superstore assets' identified as 'an integral part of the financing of recent and future acquisitions'. (Co-operative Group Board paper, 2003, paras 3.5-3.6). A sale to Tesco was announced publicly in July 2003 and completed four months later. Tesco quickly refurbished the CGL store and reopened it as a Tesco-branded unit in January 2004, while simultaneously trading its 60,000 sq ft Brunel Way store that was located only half a mile away $(\mathrm{CC}, 2007 \mathrm{c})$.

The strategic intent of Tesco for the acquisition was soon made clear. The retailer's existing $60,000 \mathrm{sq} \mathrm{ft}$ Brunel Way store was 'overtrading' relative to its size. Tesco suggested to regulators the store 'was suffering capacity problems' with its own research indicating 'that congestion both inside the store and in the car park was a major problem' (CC, 2007e, para 2.19). Trading the former CGL store on a temporary basis would allow a continuous Tesco superstore presence in the catchment while the Brunel Way store was demolished and rebuilt on its existing site as a 100,000 sq $\mathrm{ft}$ unit. This does not, however, explain why the CGL 
store was traded alongside the existing Brunel Way store for a period of one year prior to any works - something which itself might be considered by some to be anti-competitive.

The initial response of UK regulators was swift. The OFT decided to refer the acquisition to the Competition Commission in February 2004, but suspended action to allow Tesco to utilise the CGL site as a temporary trading store during the redevelopment of its Brunel Way store. Importantly, Tesco had 'indicated that it would be prepared to sell the acquired Co-op store to address possible [competition] concerns' (OFT, 2004) as it was not 'Tesco's intention to continue trading from the Uxbridge Road site once redevelopment of its larger Brunel Way site was complete' (OFT, 2007, para 7). The competition concerns at the time of the CGL acquisition related to:

'...a significant prospect that this transaction would substantially lessen competition in one-stop grocery shopping in the vicinity of the former Co-op store in Slough. The OFT is concerned that by reducing choice between local one-stop-shops, the acquisition could mean higher prices, and lower quality and service, for local consumers' (OFT, 2004).

\section{Eliminating an effective competitor? Recasting the CGL store divestment}

Tesco closed its Brunel Way store for redevelopment in January 2005, and traded exclusively from the CGL store for approximately six months. The retailer then opened its larger (100,000 sq ft) redeveloped Brunel Way store on $1^{\text {st }}$ August 2005, having closed the CGL store permanently the previous day $(\mathrm{CC}, 2007 \mathrm{c})$. We earlier noted the ability of corporate firms to actively 'deploy a range of tactics to shape the governance conditions under which they operate' (Gouldson and Sullivan, 2014, p 2975). Important for the competition concerns relating to this case, Tesco set about re-constituting the nature of the CGL divestment. The retailer was not simply intending to divest the CGL store as the OFT suggested that Tesco had indicated that it was prepared to do (OFT, 2004). Instead, while Tesco traded from the CGL store between January 2004 and July 2005, it was also progressing plans for the development of a four (initially five) unit retail park on the CGL site.

Tesco applied for planning permission for this development in May 2004, and Slough Borough Council granted consent on December 2004 (CC, 2007c). It was proposed that only one of these significantly smaller retail park units would be used for grocery retailing. Only Units 1 and 3 of the proposed retail park were suitable for conversion to a foodstore, and 
would result in a $18,400 \mathrm{sq} \mathrm{ft}$ or alternatively a $27,300 \mathrm{sq} \mathrm{ft}$ store respectively - a considerable decrease compared to the $46,000 \mathrm{sq} \mathrm{ft}$ original CGL store. In addition, both units contained a mezzanine floor which was widely known to be unattractive to major food retailers. The development would also contain fewer car parking spaces than the original CGL store nor would it offer a petrol filling station as the original did (CC, 2007e).

From one perspective, the recasting of the divestment might be framed as apparent corporate opportunism to reduce the attractiveness, size and competitive threat of the divested store in the face of regulatory action. As Bathelt and Glückler (2014) note, while institutions may constrain or limit economic action, they also offer opportunity generating capabilities for firms. As a successful corporate firm, Tesco, was resource-rich in terms of timely legal advice, possessed astute and responsive store location planning capabilities and therefore became arguably relatively powerful in comparison to the more bureaucratic state regulators. Such a situation underscores power as being contextual and relational rather than necessarily inscribed ( $c f$. Allen, 2008). However, the regulatory waters were muddied by a seeming lack of clarity from the OFT in this instance. Following the agreement to divest the CGL store in February 2004, the regulator subsequently wrote to Tesco in June implying that the ability to divest the site 'as is' to another leading large format food retailer would be limited due to competition concerns given their existing presence in the market:

'on the basis of the information we have at present, the isochrone analysis we have received indicates that none of the major one stop store operators would be eligible purchasers of the [CGL] Uxbridge Road Store' (CC, 2007e, para 3.37 quoting the OFT in June 2004).

Interestingly, the OFT subsequently argued to the Competition Commission that this comment was made in the context of how the 'market value' of the CGL store would be determined, and that it was never intended to be an analysis of the merger situation (CC, 2007, para 3.37). Nevertheless, given the OFT's statement, Tesco argued that the retail park redevelopment of the CGL site was necessary to make the site commercially attractive to Waitrose, a smaller format food retailer, that had expressed interest in the site and, given its lack of presence in the catchment, would be an eligible purchaser (OFT, 2007, para 11). In July 2004, the OFT approved the retail park 'Waitrose option' in principle - in doing so, 
changing the nature of the divestment from being the existing CGL superstore to a considerably smaller foodstore situated on a retail park (CC, 2007e, para 3.37).

In February 2005, following Slough Borough Council's earlier approval of Tesco's plans to develop the retail park, the application was 'called in' by the Government Office for the South-East, which at that time discharged planning functions on behalf of the then Office of the Deputy Prime Minister. Planning applications were 'called in' for further assessment by a planning inspector if they conflicted with national policy on important matters or were nationally significant (Guy, 2007). Importantly though, this assessment could not be on the basis of concerns over a lessening of competition in the catchment - instead, it was from the perspective of land-use planning policy (at this time PPG6 and PPG13). It involved a public inquiry into the planning application, conducted by an independent planning inspector, who then reported to the Secretary of State (Hoile, 2005). Following the public inquiry, consent for Tesco's proposed retail park development was granted by the Secretary of State in March 2006, approximately one year after the application had originally been 'called in'. Tesco commenced demolition of the CGL store in November 2006 and started construction of the retail park on the former CGL site in March 2007 (CC, 2007c).

There was some disagreement regarding the time it took the retailer to declare to the OFT that the so-called 'Waitrose option' for the proposed retail park had started to unravel. Tesco suggested that it informed the OFT in November 2004 of Waitrose's withdrawal of interest in a unit in the proposed retail park development (CC, 2007e, para 3.41). In contrast, the OFT suggested it only became aware of this ten months later, in August 2005 (ibid. para 3.41). Indeed, the OFT (2007, para 15) argued the retailer responded to its inquiries on several occasions after planning consent was granted - including in writing in May, September and November 2006 - noting 'that it was actively marketing the site and was confident of finding a suitable purchaser'.

During the period after August 2006, the OFT became increasingly concerned at the apparent lack of progress to identify a suitable occupant for the proposed modestly sized food retail unit on the retail park site that was being constructed by Tesco (CC, 2007e, para 3.42). In January 2007 the OFT informed the retailer that, for its duty to refer the acquisition to the Competition Commission to remain suspended, it must identify a suitable buyer within two months for either the undeveloped CGL site or the smaller foodstore unit within its planned 
retail park development. Tesco was unable to do so and therefore the retailer's acquisition of the CGL store was referred to the Competition Commission in April 2007 for a full investigation (CC, 2007c).

\section{Response - the regulatory state fights back}

It was considered by some that Tesco had acted strategically and systematically to reduce the attractiveness of the CGL site by reducing the size of the foodstore and thereby ensure that any food retailer acquiring the divestment would be in a markedly weaker position than it would otherwise have been (see The Daily Telegraph, 2009). Sainsbury's, a key competitor for Tesco, suggested in their submission to the competition authorities that the retail park development 'diminishes the value of the site, because it mixes food and non-food retail'; they pointed to the loss of car parking spaces and a petrol filling station as well as the addition of mezzanine floors meaning it had become 'very unattractive to a grocery retailer' (CC, 2007d). Journalists quoted one retail executive from a competitor who expressed their view in an uncompromising manner:

'Tesco has cynically exploited the situation. It now totally dominates an area where it was already the strongest player having effectively taken a competitor out of the market' (The Daily Telegraph, 2007)

While competitor executives inevitably present a one-sided perspective, they reflect the considerable local and national outcry that persisted relating to the developments. Yet, such a binary view underplays the manner in which the regulatory state itself contributed to the shift away from simply divesting the CGL store 'as is'. Given the OFT's suggestion to Tesco in June 2004 that divesting the CGL store to a leading large format food retailer would be unlikely due to competition concerns, it might be seen as entirely logical for the retailer to recast the divestment as a retail park, albeit with a markedly smaller food store for an apparently interested (and eligible) party in the form of Waitrose. Indeed, the OFT agreed 'in principle' to this approach in July 2004.

Irrespective of blame, it was clear that an impasse had been reached with little progress on the proposed divestment (OFT, 2007, para 16). However, as Gouldson and Bebbington (2007) note, while the regulatory state is often reluctant to draw on their capacities for control, they will leverage their authority as a last resort when other forms of influence prove 
unavailable or ineffective. In May 2007, the Competition Commission (2007a) published an 'issues statement' as part of its inquiry in order to assess whether there had been a 'substantial lessening of competition' and, if so, what remedies might be appropriate. The following month (June 2007), the Commission accepted 'interim undertakings' by Tesco which included a requirement for the retailer to apply for an amendment to the planning permission to increase the size of the foodstore on the retail park by merging Units $3 \& 4$ of the proposed development for the sale of food (CC, 2007b).

In undertaking its inquiry, the Competition Commission's (2007e) analysis concluded that had the CGL store been acquired by a competitor, it would have acted as a "primary competitive constraint on Tesco Brunel Way' (CC, 2007c, para 7.46) - however, instead 'the acquisition of the CGL store by Tesco has resulted, and may be expected to result, in a SLC [substantial lessening of competition] in the relevant market [...leading] to reduced store choice for Slough residents' (CC, 2007e, para 7.70). Furthermore, the Competition Commission (2007c, para 7.1) commented, 'it is not clear that the retail park being constructed by Tesco will contain a grocery retailer that would create a level of competition that would have existed [had the acquisition not occurred]'. Tesco was made to cease construction of the retail park on the CGL site in August 2007. The Competition Commission's ruling that followed in November 2007 was for a complete redevelopment of the CGL site for one large food retailer that would act as an effective competitor for the redeveloped Tesco Brunel Way (CC, 2007e; 2009).

The strict enforcement of the Competition Commission Inquiry in requiring divestment of the entire CGL site for a superstore was inconsistent with first, the OFT's earlier statement that implied no leading large format food retailer would likely be eligible to acquire the divested CGL store due to competition concerns; and second, its subsequent agreement to Tesco's proposed retail park redevelopment on the CGL site which implied a smaller divested foodstore. This points to notable inconsistencies in the practical management and interpretation of competition regulation between the two regulatory agencies. It also underlines the contextual nature of regulation and how its practical reality is embedded within relational interchange between the regulator(s) and the regulated ( $c f$. Bathelt and Glückler, 2014; Clark, 1992). In addition, the requirements of the Competition Commission differed from those that had earlier emanated from Slough Borough Council's adjudication on Tesco's retail park proposal. This is more easily explained given the divergent nature and 
goals of competition and land-use planning regulations. When considering the application of Tesco to develop a retail park, the Council was forced to assess the submission in terms of enforcing 'town centre first' land-use planning policy rather than issues relating to competition or market power. Concerned that the CGL store might otherwise be subdivided and used for discount retailing of clothes and other 'comparison' goods, the Council contended that Tesco's proposed retail park 'would attract retailers that would complement rather than compete with, the retail offer already present in the town centre' $(\mathrm{CC}, 2007 \mathrm{c}$, para. 3.22).

Following the findings of the Competition Commission Inquiry at the end of 2007, Slough Borough Council approved outline planning applications from two food retailers, Sainsbury's and Morrisons, for new-build large standalone stores on the entire CGL site in November 2009 (Slough Borough Council, 2010). Sainsbury's were confirmed as the approved purchaser in November 2009, opening a 55,000 sq ft superstore on the site 12 months later to provide what was considered an effective competitor for Tesco and other retailers within the Slough catchment.

\section{Discussion and Conclusions}

The use of a case study has allowed us to explore the relational power geometries which play out between state regulators interacting with a corporate retail firm at a local scale. This final section offers broad theoretical as well as retail sector specific conclusions that are worthy of some discussion to which we now turn.

First, at the localised spatial scale of the individual catchment and through a focus on the relational interchange between regulator and the regulated corporate firm we are able to expose the relational and situational nature of regulatory assessment and enforcement ( $c f$. Jones, 2014). On the one hand, the research has served to 'bring the firm back in' where they are recognised as an agent with proactive capacities for action, exhibiting innovative responses to 'operate in ways that do not necessarily reflect the dominant institutional logic' (Hsu, 2012, p 394). On the other, we find that market rules mean little until they are placed in context - as Peck (2012, p 296) reflects, 'regulatory regimes and institutional "shells" are not simply out there, distant from the control and influence'. Instead, we see conflicting and overlapping contests for power with different interpretations of market rules, as the state is challenged to make sense, and to act swiftly in support of a public good ( $c f$. Clark, 1992). 
Consistent with Levi-Faur (2013, p 45), put simply, it all depends 'on the ways regulation is applied and on its context'.

Normative judgements relating to regulatory interpretation and enforcement are often not as clear cut as government policy documents might suggest: in this specific instance, there were even markedly divergent perspectives between the two competition regulators (OFT and Competition Commission) regarding the form that divestment should take. Given this context, it is plausible that Tesco re-cast divestment such that it would pose less intense competition to its existing store assets within the catchment. Indeed, one might argue there were few alternatives for the retailer given the suggestion by the OFT that none of the major one stop store operators would be eligible to acquire the divested CGL store due to competition concerns. As such regulatory practice can not only 'function as an arena in which rules are implemented, enforced and reinterpreted' but also offer an opportunity for 'the reformulation of rules and regulation in their own right' (Harrison et al., 1997, p.485). While innovation and creativity are instrumental elements of capitalism, there are key roles for regulators in ensuring these are within the spirit and goals of the regulatory frameworks they are tasked with enforcing. To do otherwise risks urban geographies that result in decreased consumer welfare. In this instance, the state eventually resolved to re-create a more competitive local geography within the catchment than would otherwise likely have evolved.

Second, the case study is also illuminating concerning the importance of resources and power in relational encounters between state regulators and corporate firms. Large corporate firms leverage their extensive resources in lobbying to Government and regulators, with their arguments grounded in well-informed (and costly) legal opinion (Pal and Medway, 2008). In contrast, smaller firms often lack this capability, with state regulators sometimes similarly resource constrained. While the state might be seen as possessing structural power embedded in their role as regulator or upholder of the law, resources and power are not necessarily the same thing (Allen, 2008). What matters is the ability to - and manner in which - resources are used in practice to influence outcomes in a particular context. As such, power is inherently relational - "not power, first, and then place "added in" to see what difference it makes; power on this view is always already spatial' (Allen, 2008, p 1619). Within the case study, the ability to act decisively was hampered by the complex arrangement of the OFT and the Competition Commission both being focused on competition regulation and arriving at 
markedly different conclusions regarding any resolution. Such divergence likely prevented the necessary timely and effective response of wholesale divestment of the site for a large store to a competitor.

Third, there is an evolutionary perspective to this case study with regards to the development of regulatory infrastructure and enforcement over the eight year period under review. As MacLeavy and Harrison (2010, 1037-8) note in a more general context, it is important to frame the state as emergent and forged through 'ongoing engagements between agents, institutions and concrete political and policy circumstances' rather than necessarily as passive. The case study thus highlighted the over-complex nature of referral and decisionmaking between state agents responsible for UK competition policy which contributed to the delay in responsiveness to an uncompetitive local geography. As Wilks (2011, p 5) recognised more widely; 'inter-agency tension and jurisdictional overlap increases costs, creates delay, reduces clarity and limits deterrent effects'. Subsequent re-organisation has since occurred in the institutional apparatus of competition regulation. The evolution and simplification provided by the formation of the Competition and Markets Authority (CMA) in 2014, which took over many of the functions of the previous OFT and Competition Commission, offers the promise of a more responsive regulatory infrastructure. In doing so, it underlines that the 'state as regulator' itself adapts given changing geographies and evolving institutional demands for governance.

Fourth, specifically in terms of the regulation of retailing, the case raises the issue of possibly ineffective store divestitures and the subsequent need for the competition authorities to intervene swiftly. This has been a particular concern within the United States and centred on the need to divest ongoing businesses (e.g. trading stores) to credible operators because evidence suggests divesting retailers otherwise 'tend to look for marginally acceptable buyers and may engage in strategic conduct to impede the success of the buyer' (FTC, 1999, p.8). Recent UK evidence suggests that lessons are being learnt in this regard. For example, in the acquisition by Asda of Netto's entire UK 194 supermarket estate in 2010, the OFT insisted the acquirer identify 'upfront buyers' for 25 of the 47 divested stores and 'carefully assessed the financial position and commitment of all prospective purchasers, before accepting the undertakings' (OFT, 2011). The concern with effective divestments clearly remains fundamental to merger resolution within retailing. 
Finally, the exchanges between regulators and the regulated corporate firm expose significant challenges to the implementation of market rules focused across different spatial scales. While the multi-scalar nature of governance and regulation is often discussed within economic geography, this case study has highlighted the manner in which locally focused and executed land-use planning policy with a specific remit to protect town centres by local authorities came to produce judgements that differed from the decisions of national regulators dealing with competition policy. While this mismatch in terms of the spatial scale and objectives of the two forms of regulation has been noted in the past, proposals to address it in the form of a so-called Competition Test never reached the statute book. The implications of differing outcomes of the two forms of regulation which address different issues and are administered from different scales remain an enduring challenge that can only be properly understood in a practical context - something we believe this paper has allowed us to gain some insight into.

\section{References}

Allen J, 2003 Lost Geographies of Power (Blackwell, Oxford, UK)

Allen J, 2008, "Pragmatism and power, or the power to make a difference in a radically contingent world" Geoforum 39 1613-1624

Bathelt H, Glückler J, 2005, "Resources in economic geography: from substantive concepts towards a relational perspective" Environment and Planning A 37 1545-1563

Bathelt H, Glückler J, 2014, "Institutional change in economic geography" Progress in Human Geography 38 340-363

Cheshire P C, Hilber C A L, Kaplanis I, 2015, "Land use regulation and productivity-land matters: evidence from a UK supermarket chain" Journal of Economic Geography 15 43-73

Clark G L, 1992, "'Real' regulation: the administrative state" Environment and Planning A 24 $615-627$

Clarke I, Kirkup M, Oppewal H, 2012, "Consumer satisfaction with local retail diversity in the UK: effects of supermarket access, brand variety, and social deprivation" Environment and Planning A 44 1896-1911

Coe N M, Yeung H W-C, 2015 Global Production Networks: Theorizing Economic Development in an Interconnected World (Oxford University Press, Oxford, UK)

Competition Appeal Tribunal [CAT] 2009, Tesco plc - The Competition Commission Judgment, Case Number: 1104/6/8/08, 4 March 
Competition Commission [CC] 2007a, News Release: Acquisition by Tesco of Co-op Store in Slough, 31 May

Competition Commission [CC] 2007b, News Release: Interim Undertakings Accepted in Tesco/Slough Inquiry, 15 June.

Competition Commission [CC] 2007c, Acquisition of the Co-operative Group's Store at Uxbridge Road, Slough, by Tesco plc. Provisional Findings Report, 21 September.

Competition Commission [CC] 2007d Summary of hearing with Sainsbury's - The sale of the Uxbridge Road site, 28 June.

Competition Commission [CC] 2007e, Tesco plc and the Co-operative Group (CWS) Limited. A report on the acquisition of the Co-operative Group (CWS) Limited's store at Uxbridge Road, Slough, by Tesco plc, 28 November.

Competition Commission [CC] 2008 The Supply of Groceries in the UK Market Investigation (HMSO, London)

Competition Commission [CC] 2009, In The Matter Of A Reference To The Competition Commission Dated 19 April 2007 Concerning The Completed Acquisition By Tesco Plc Of The Co-Operative Group Limited's Store At Uxbridge Road, Slough, 23 April.

Competition Commission/Office of Fair Trading [CC/OFT] 2011, Commentary on Retail Mergers, March 2011 (HMSO, London)

Co-operative Group Board paper, 2003 Proposed store disposal paper for its South East regional board, 17 June

The Daily Telegraph 2007, "Rivals angry as Tesco demolishes Co-op store" 16 January

The Daily Telegraph 2009, "Site sale ends Tesco stratagem" 22 November

Dobson P W, 2006, "Exploiting buyer power: lessons from the British grocery trade" Antitrust Law Journal 72 529-562

Dobson P W, Chakraborty R, 2008, "Buyer power in the U.K. groceries market" Antitrust Bulletin 53 333-368

Dobson P W, Waterson M, 2005, "Chain-store pricing across local markets" Journal of Economics \& Management Strategy 14 93-119

Faulconbridge J R, 2012, "Economic geographies of power: Methodological challenges and interdisciplinary analytical possibilities" Progress in Human Geography 36 735-757

Faulconbridge JR, in press, "Relational geographies of knowledge and innovation", in The Elgar Companion to Innovation and Knowledge Creation Eds. $\mathrm{H}$ Bathelt, $\mathrm{P}$ Cohendet, $\mathrm{S}$ Henn, L Simon (Edward Elgar, London). 
FTC [Federal Trade Commission] 1999 A Study of the Commission's Divestiture Process. Prepared by the Staff of the Bureau of Competition of the Federal Trade Commission. Available for download at http://www.apeccp.org.tw/doc/USA/Policy/usapol02.pdf

Flyvbjerg B, 2006, "Five misunderstandings about case-study research" Qualitative Inquiry 12 219-245

Gouldson A, Bebbington J, 2007, "Corporations and the governance of environmental risk" Environment and Planning C: Government and Policy 25 4-20

Gouldson A, Sullivan R, 2014, "Understanding the governance of corporations: an examination of the factors shaping UK supermarket strategies on climate change" Environment and Planning A 46 2972-2990

Guy C, 2007 Planning for Retail Development (Routledge, London)

Guy C, Bennison D, 2007, "Planning guidance and large-store development in the United Kingdom: the search for 'flexibility'" Environment and Planning A 39 945-964

Harrison M, Flynn A, Marsden T, 1997, "Contested regulatory practice and the implementation of food policy: Exploring the local and national interface" Transactions of the Institute of British Geographers 22 473-487

Hoile C J, 2005, Inspector appointed by the First Secretary of State, Application by Spen Hill Developments Limited, 78 Uxbridge Road, Slough, Report to the First Secretary of State, 5 October.

Hsu J-y, 2012, "Bringing politics back in: Reading the firm-territory nexus politically", in The Wiley-Blackwell Companion to Economic Geography Eds. J Peck, E Sheppard (Blackwell, Oxford, UK) pp 385-398

Hughes R, Hallsworth A G, Clarke G, 2009, "Testing the effectiveness of the proposed UK 'competition test'" The Service Industries Journal 29 569-590

Jessop B, 2004, "Hollowing out the 'nation-state' and multilevel governance", in A Handbook of Comparative Social Policy Ed P Kennett (Edward Elgar Publishing, Cheltenham) pp 11-25

Jones A, 2014, "Geographies of production I: Relationality revisited and the 'practice shift' in economic geography" Progress in Human Geography 38 605-615

Levi-Faur D, 2013, "The odyssey of the regulatory state: from a 'thin' monomorphic concept to a 'thick' and polymorphic concept" Law \& Policy 35 29-50

MacLeavy J, Harrison J, 2010, "New state spatialities: Perspectives on state, space, and scalar geographies" Antipode 42 1037-1046

Office of Fair Trading [OFT] 2004, Press release- OFT to refer Tesco acquisition of Slough Co-op store unless undertakings are given, 2 February 
Office of Fair Trading [OFT] 2007, Completed acquisition by Tesco plc of the Co-operative Group (CWS) Ltd store at Uxbridge Road, Slough, 9 May.

Office of Fair Trading [OFT] 2011, Press releases 2011 - Asda/Netto: OFT accepts divestment undertakings, 9 March

Pal J, Medway D, 2008, "Working the system" Environment and Planning A 40 761-765

Peck J, Barnes T J, Sheppard E, 2012, "Editors' Introduction: Regulation and Governance ", in The Wiley-Blackwell Companion to Economic Geography Eds. J Peck, T J Barnes, E Sheppard (Blackwell, Oxford, UK) pp 291-297

Poole R, Clarke G P, Clarke D B, 2006, "Competition and saturation in West European grocery retailing" Environment and Planning A 38 2129-2156

Powe N A, 2012, "Small town vitality and viability: learning from experiences in the North East of England" Environment and Planning A $\mathbf{4 4}$ 2225-2239

Slough Borough Council, 2010, Agenda and Minutes: Planning Committee -17 March.

Sparks L, 2008, "When Tony met Bobby" Environment and Planning A 40 2793-2799

Sunley P, 2008, "Relational economic geography: a partial understanding or a new paradigm?" Economic Geography 84 1-26

Wilks S, 2011, "Institutional reform and the enforcement of competition policy in the UK" European Competition Journal 7 1-23

Wood S, 2001, "Regulatory constrained portfolio restructuring: the US department store industry in the 1990s" Environment and Planning A 331279

Wood S, 2013, "Revisiting the US food retail consolidation wave: regulation, market power and spatial outcomes" Journal of Economic Geography 13 299-326

Wood S, Lowe M, Wrigley N, 2010, "Conceptualising innovative customer-facing responses to planning regulation: the UK food retailers" The Service Industries Journal 30 1967-1990

Wrigley N, 1998, "Understanding store development programmes in post-property-crisis UK food retailing" Environment and Planning A 30 15-35

Wrigley N, 2001, "Local spatial monopoly and competition regulation: reflections on recent UK and US rulings" Environment and Planning A 33 189-194

Wrigley N, 2010, "The shifting geographies of UK retailing", in The Economic Geography of the UK Eds. N Coe , A Jones (Sage, London) pp 181-195

Wrigley N, Branson J, Murdock A, Clarke G, 2009, "Extending the Competition Commission's findings on entry and exit of small stores in British high streets: implications for competition and planning policy" Environment and Planning A 41 2063-2085 
Wrigley N, Dolega L, 2011, "Resilience, fragility, and adaptation: new evidence on the performance of UK high streets during global economic crisis and its policy implications" Environment and Planning A 43 2337-2363

Wrigley N, Lambiri D, 2014, High Street Performance and Evolution: A Brief Guide to the Evidence, (School of Geography, University of Southampton, UK)

Yeung H W, 2005, "Rethinking relational economic geography" Transactions of the Institute of British Geographers 30 37-51 
Figure 1: Slough Local Catchment in Context of Large Stores in the Vicinity, 2003 (Scale 1: 21538)

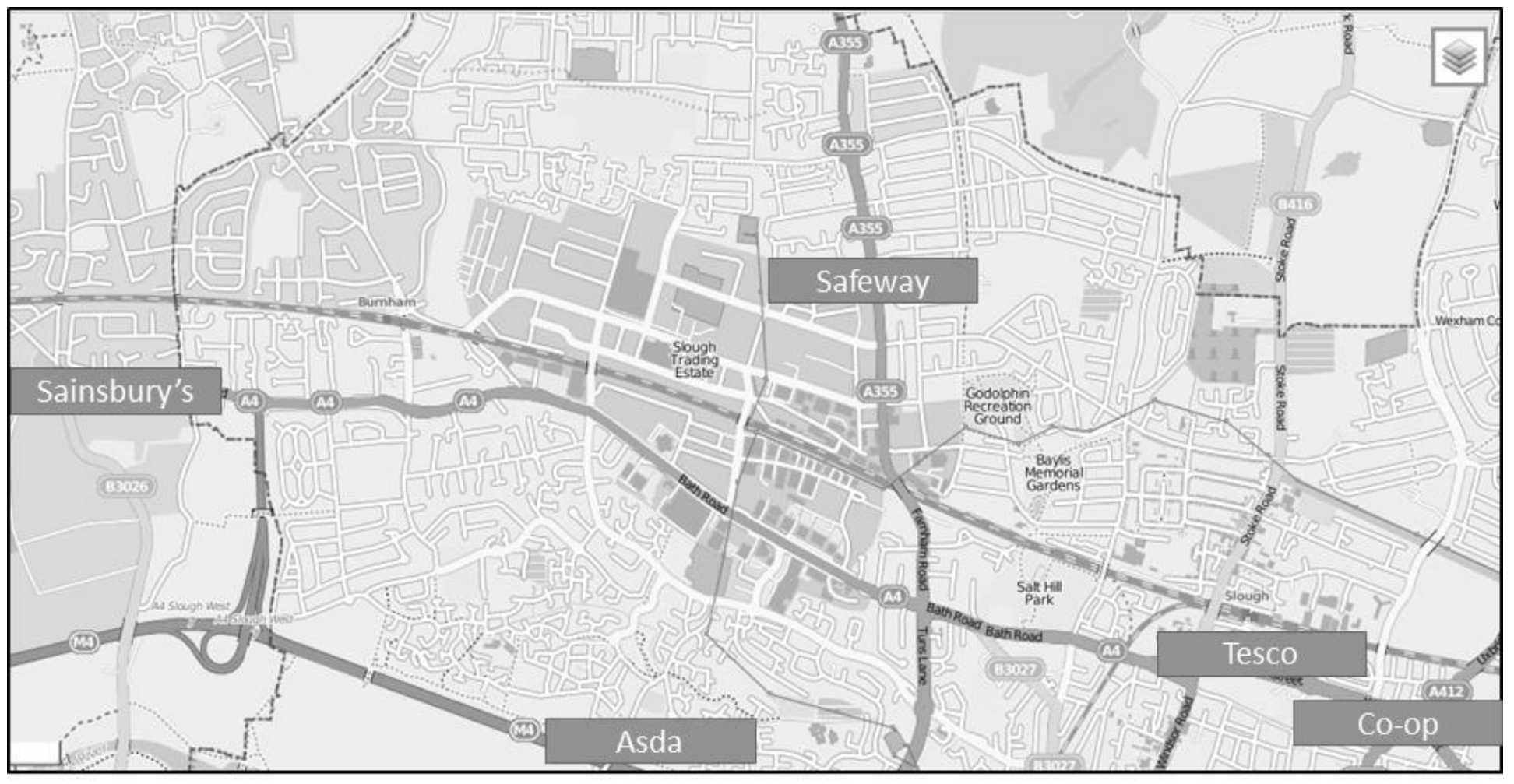

Co-op (Uxbridge Road) (46,000 sq ft) superstore with petrol filling station and 450 car parking spaces

Tesco Extra (Brunel Way) (60,000 sq ft) situated approx. $800 \mathrm{~m}$ to the west of the Co-op on Uxbridge Road

Asda (Telford Way) (59,000 sq ft) approximately 10 minutes' drive-time away from the Co-op on Uxbridge Road

Safeway (Farnham Road) (15,000 sq ft) located 5 to 10 minutes' drive-time from the Co-op on Uxbridge Road

Sainsbury's (Taplow) (32,300 sq ft), located 10-15 minute drive-time from the Co-op on Uxbridge Road. 